\title{
Pleurostachys (Cyperaceae): nomenclatural notes, geographical distribution and conservation status
}

\author{
Marccus Alves ${ }^{1,3}$ \& William Wayt Thomas ${ }^{2}$
}

\begin{abstract}
Pleurostachys Brongn. is a Neotropical genus of Cyperaceae closely related to Rhynchospora Vahl. It is found in the Atlantic and Amazon Forests from northern South America to southern Brazil and most of the species grow in the humid and shady understory. Fourteen species are confirmed, 11 of them are endemic to the Brazilian Atlantic Forest and six are considered under the conservation status of Vulnerable. New synonyms and lectotypes are also indicated.
\end{abstract}

Key words: Atlantic Forest, Neotropics, Rhynchospora, Conservation, Poales.

\section{Introduction}

Pleurostachys Brongn. is a Neotropical genus of Cyperaceae with a restricted distribution, being mainly found in the Atlantic Forest, humid forests which run along the Brazilian coast (Thomas \& Alves, 2008). Almost 35 valid names are cited for the genus by Govaerts et al. (2007), and 14-20 of them have been accepted by Guaglianone et al. (2008) and Alves et al. $(2009,2014)$ for Brazil. This shows that Brazil is a center of diversity of the genus.

Its close morphological alliance to Rhynchospora Vahl has been pointed out by several authors including Pfeiffer (1925), Smith (1934) and Kükenthal (1952). In more recent studies both genera emerge mixed up (Goetghebeur, 1998; Thomas et al. 2009) and the phylogenies show no support for them being separate genera (Thomas \& Alves 2008; Thomas et al. 2009) neither for Pleurostachys nor Rhynchospora.

Both genera are clearly recognized by a combined set of morphological characters (tribe Rhynchosporeae), such as simple spikelets, bisexual flowers, lenticular achenes subtended by perianth bristles, and a persistent style base (Goetghebeur 1998; Thomas et al. 2013). However, Pleurostachys can be distinguished by the distichously (or rarely subdistichously) vs. spiral-like arranged spikelet scales, distally plumose vs. non-plumose to scabrid perianth bristles, and decurrent vs. short-decurrent to truncate style bases (Goetghebeur 1998; Thomas \& Alves 2008; Thomas et al. 2013).

The last taxonomic treatment and the infrageneric classification were provided by Kükenthal (1952). He accepted the seven following sections: P. sect. Angustifoliae Kük., P. sect. Foliosae Pfeiff., $P$. sect. Martinae Pfeiff., $P$. sect. Millegranae (Benth. \& Hook.) Pfeiff., $P$. sect. Scaposae Kük., P. sect. Sparsiflorae Kük., and $P$. sect. Tenuiflorae Pfeiff. Later, Thomas \& Alves (2008) stressed that most of the sections are supported by neither the preliminary phylogeny nor when using morphological characters which are highly overlapped.

Since then, only a few studies related to Pleurostachys have been made available. These are mainly restricted to a world checklist of Cyperaceae (Govaerts et al. 2007), a checklist of the Brazilian species and their geographical distribution (Alves et al. 2009, 2014), a new species recently described from Brazil (Thomas et al. 2013) and nomenclatural notes (Longhi-Wagner et al. 2010).

The approach employed here provides general data available about species of Pleurostachys and their related names, including synonyms, and types. Besides that, information on geographical

\footnotetext{
${ }^{1}$ Universidade Federal de Pernambuco, Depto. Botânica, Av. Moraes Rego s/n, 51930-630, Recife, PE, Brazil. Temporary address: Herbarium Senckenbergianum, Frankfurt am Main, Germany. 60-325.

${ }^{2}$ The New York Botanical Garden, Bronx., New York, 10458-5126, USA.

${ }^{3}$ Author for contact: alves.marccus@gmail.com
} 
distribution, conservation status based on categories by the IUCN (2012) and some diagnostic characters are also presented.

\section{Methods}

This study made use of extensive collections which have been made by the authors over the last 10 years. They include samples from field expeditions all over Brazil, but especially along the coastal Atlantic Forest, from the state of Paraíba to Santa Catarina.

Samples collected have been primarily deposited at the UFP herbarium, with duplicates at CEPEC, NY, RB, SP, and SPF, among others.

In addition, morphological and geographical data were collected from samples examined at the following herbaria: ALCB, ASE, B, BHCB, BM, BOLO, CVRD, FLOR, FR, FURB, G, GOET, GUA, HB, HBG, HBR, HPZ, HRR, HST, HUEFS, HUESB, IAN, ICN, INPA, IPA, JPB, K, M, MBM, MBML, NY, P, PAD, PEUFR, R, RB, S, SP, SPF, UFP, UB, UPCB, US, W, and WU.

The conservation status follows the criteria adopted by the IUCN (2012). Under the "representative material examined", up to five samples are cited to represent the range of distribution, habitats and morphological variation of each species.

\section{Results and Discussion}

Pleurostachys is here also confirmed as a genus endemic to the tropical and subtropical areas of South America (Goetghebeur 1998; Govaerts et al. 2007; Thomas et al. 2009). It is often found in the understory of humid and shady forests and close to streams. A few species can also be found in open vegetation, such as rocky outcrops and sandy soil, as is the case of $P$. stricta Kunth.

Govaerts et al. (2007) cited 33 species and Alves et al. (2014) 18, but only 14 of them are recognized here. Two names are new synonym and two others remain to be confirmed as valid species - $P$. peruviana C.B. Clarke and $P$. pearcei both described from Peru. Types of these names have not been located yet and descriptions are not complete enough for a taxonomic decision.

All 14 accepted taxa are found in Brazil and three of them also grow in Bolivia, Colombia, French Guyana, Guyana, Ecuador, Peru, Suriname, Trinidad \& Tobago, and Venezuela - P. orbignyana Brongn., P. scaposa C.B. Clarke and P. sparsiflora
Kunth. The three species are associated with the Amazon Forest. In the Brazilian Amazon Forest, Pleurostachys is found in the states of Acre, Amazonas, Pará and Rondônia.

The Atlantic Forest is clearly the center of diversity of the genus with 12 species, some of which are narrow endemics such as $P$. bradei R. Gross, P. pilulifera (Bertol.) Longhi-Wagner, Baldini \& A.C. Araújo, and P. rabenii Boeck. Pleurostachys can be found from the state of Pernambuco (P. orbignyana Brongn.) to Rio Grande do Sul (P. gaudichaudii Brongn. and $P$. stricta Kunth). All species recorded from the Atlantic Forest are also found in the state of Rio de Janeiro which makes this the most species-rich state for the genus. It is followed by the states of São Paulo (10 species and 2 to be confirmed) and Minas Gerais, Paraná and Santa Catarina (8 species each).

Pleurostachys orbignyana is the only example of disjunction between the Atlantic and Amazon Forests and is the most widely distributed species of the genus. It is also the species with the longest north-south occurrence range in the Atlantic Forest, being found from the states of Pernambuco to Santa Catarina. This pattern is common in Cyperaceae and has previously been related to Hypolytrum (Alves et al. 2003), a genus found mainly in humid and shady forests, as is true with Pleurostachys.

Even growing in well established populations and with most species found in preserved natural areas, six species are here considered under the conservation status of Vulnerable (VU) because of their narrow-restricted to restricted distributions.

Some taxa are highly morphologically variable, making their correct identification difficult. It is possible that more studies using population analyses and molecular tools will provide a better understanding of their limits as maybe different taxa. This reality can be seen in $P$. orbignyana and also in a group of closely related species: P. bradei, $P$. rabenii and $P$. stricta.

Some nomenclatural types were not found and were possibly destroyed during the II World War at Herbaria as B, HBG and BREM. A couple of them were also not located at the herbarium were the authors of the names had spent most of their professional time and where the samples could be is a mystery. Kukenthal was a very active cyperologist, including reviewing Pleurostachys, in Germany during 1936-1945 and we assume that some specimens were being studied by him 
during this time and got lost. Nemochloa beyrichii Nees, P. angustifolia Boeck., P. paniculata Boeck., and P. schottmulleri Boeck. are among the names (all of them are considered synonyms) which the nomenclatural types were not found and are probably destroyed. For these names, because of the lack of other specimens with any indication that were studied by the authors of the names, we decided to not designate lectyoypes for now.

In summary, this work updates current knowledge of the diversity of the genus, with 14 species, 11 of them confirmed as endemic to the Brazilian Atlantic Forest, around 20 names lectotypified, 14 new synonyms indicated and more than 50 type-specimens located.

1. Pleurostachys arcuata W. W. Thomas, M. Alves \& R. Trevis., Phytotaxa 126(1): 31. 2013. Type: Brazil. Bahia: Mun. Santa Luzia, Serra da Onça. 21 nov 1996. W. W. Thomas et al. 11367 (holotype CEPEC!, isotypes G!, K!, NY!).

Endemic to Brazil and widespread in the central-southern part of the Atlantic Forest from the states of Bahia to Santa Catarina, including Minas Gerais (Thomas et al. 2013; Alves et al. 2014). It is found in well-established populations and in several protected forest fragments and classified by Thomas et al. (2013) as VU (Vulnerable). This species can be easily recognized by the leafy culm and the arrangement of the spikelets in the synflorescence. Representative material examined: BRAZIL. BAHIA: Jussari, Reserva Serra do Teimoso, 15.IX.2001, J. Jardim et al. 3922 (CEPEC, NY). ESPIRITO SANTO: Cariacica, Reserva Biológica de Duas Bocas, 1.VI.2000, M. Alves et al. 1945 (MBML, SP). RIO DE JANEIRO: Paraty, Morro do Córrego dos Micos, 26.XI.1994, M. Bovini et al. 647 (RB). PARANÁ: Guaraqueçaba, Rio de Costa, 4.II.1971, G. Hatschbach 26270 (MBM, NY). SANTA CATARINA: Blumenau, Parque Natural Municipal São Francisco de Assis, 18.II.2011, M. Verdi 5889 (FLOR, FURB).

2. Pleurostachys bradei R. Gross, Repert. Spec. Nov. Regni Veg. 29: 245. 1931. Type: Brazil. Rio de Janeiro, Serra do Itatiaia, Maromba, 30.VI. 1930, A. Brade 10265 (holotype B not found and probably destroyed, lectotypes RB!, isolectotypes F!, MO!, R! - designated here).

$=$ P. bradei var. alata Kük. \& R. Gross in Kük., Bot. Jahrb. Syst. 75(4): 472. 1952. Type: Brazil. Rio de Janeiro, Serra do Itatiaia, 1933, A. Brade 12720 (holotype B!, isotype: MO!, RB!, UB!).

Endemic to Brazil and found in very restricted submontane and montane areas of Atlantic Forest in the south of the state of Rio de Janeiro bordering the states of São Paulo and Minas Gerais (Alves et al. 2014). A few samples are available in local herbaria and the narrow-endemic distribution of the species in a National Park suggests it as VU. This species can be recognized by the spikelets clustered in short-branched inflorescence supported by a long and thin axis.

Material examined: BRAZIL. RIO DE JANEIRO: Itatiaia, Maromba, VIII.1933, A. Brade 12643 (RB), 26.VII.1996, G. Eiten \& L. Eiten 7459 (MO, UB); Tinguá, Represa do Rio Piaba, 28.VIII.1960, G. Pabst 5396 (HB).

3. Pleurostachys distichophylla (Boeck.) C.B. Clarke, Kew Bull. Add. Ser. 8: 42. 1908. Rhynchopsora distichophylla Boeck., Kjobenh. Vidensk. Meddel. 1879/1880: 26. 1879/1880. Type: Brazil. Rio de Janeiro, s.d., Glaziou 14384 (holotype $\mathrm{K}$ !; isotypes $\mathrm{G}$ !, $\mathrm{P}$ !).

$=P$. densifoliata H. Pfeiff., Feddes Repert. 17: 233. 1921. Type: Brazil. Paraná, Serra do Mar, prope Ypiranga, 12.IX.1908, R. Dusén s.n. (holotype S!; photo B!).

Endemic to the Atlantic Forest in Brazil from the state of Rio de Janeiro to Santa Catarina (Alves et al. 2014) in submontane and montane forests. It is found in well-established populations in some protected forest fragments, and also in small populations. It is considered of LC (Least Concern) based on its wide area of occurrence and numerous natural populations. This species can be recognized by the leafy culm with linear leaves on the final third of the culm which resembles the arrangement of the leaves found in some understory species of Bambusoideae - Poaceae (Renvoize 1984).

Representative material examined: BRAZIL. RIO DE JANEIRO: Petrópolis, Pati do Alferes, 22.IV.1980, T. Plowman \& G. Martinelli 10116 (K, NY, RB). SÃO PAULO: Jundiaí, Serra do Japi, 8.X.1976, H. Leitão Filho et al. 3198 (NY, UEC). PARANÁ: Morretes, Parque Estadual do Pico do Marumbi, 7.VIII.1999, C. Kozera 1140 (UPCB); Quatro Barras, Morro Sete, 17.VII.2003, A. Cervi et al. 8242 (MBM). SANTA CATARINA: Campo Alegre, Morro do Iquererim, 18.X.1957, R. Reitz 3205 (HBR, NY).

4. Pleurostachys foliosa Kunth, Enum. Pl. 2: 284. 1837. Nemochloa foliosa (Kunth) Nees in Mart., Fl. bras. 2(1): 152. 1842. Rhynchospora foliosa (Kunth) L.B. Sm., Phytologia 1(2): 81. 1934. Type: Brazil. Brasilia meridionalis, s.d., Sellow s.n. (B not found and probably destroyed, G photo from B!, lectotype K! - designated here). 
= P. sellowii Kunth, Enum. P1. 2: 285. 1837. Nemochloa selowii (Kunth) Nees in Mart., Fl. bras. 2(1): 152. 1842. Type: Brazil. Brasilia meridionalis, s.d., Sellow s.n. (B not found and probably destroyed, lectotype K! - designated here). = Hypolytrum loefgrenii Boeck., Vidensk. Meddel. 1894: 239. 1895. P. loefgrenii (Boeck.) T. Koyama, Darwiniana 16:89. 1970. Type: Brazil. S. loc., s.d., Edwall 1896 (holotype C).

$=P$. longa Lindm., Bih. Svensk. Vet. Akad. Handl. 26(3-9): 29. 1900. P. foliosa var. longa (Lindm.) Kük., in sched. Type: Brazil. Rio de Janeiro, 1840, Regnell 227 (holotype S!, photo B!).

$=P$. longiradiata Palla, Denkschr. Kaiserl. Akad. Wiss., Wien. Math.-Naturwiss. K1. 79: 190. 1908. Pleurostachys selowii var. longiradiata (Palla) Kük. \& R. Gross. Type: Brazil. São Paulo, Alto da Serra, V.1901, Wettstein \& Schniffer s.n. (holotype GZU, isotype B!).

$=$ P. pauloensis Palla, Denkschr. Kaiserl. Akad. Wiss., Wien. Math.-Naturwiss. K1. 79: 1871908. Type: Brazil. São Paulo, Pilar uns Alto da Serra, bei Santos, 1902, Wacket s.n. (GZU).

=P. arrojadii H. Pfeiff., Feddes Rep. 19: 295. 1924. Type: Brazil. Bahia, São Bento, s.d., Luetzelburg 226 (holotype M!, isotype B!).

=P. cimaensis H. Pfeiff., Feddes Rep. 17: 233. 1921. Type: Brazil. Paraná, Serra do Mar, prope Porto de Cima, 19.XI.1914, G. Joansson (Dusén) 558 a (holotype B!, isotypes BM!, G!, K!, NY!).

$=$ P. geraldina R.C. Davie, J. Bot 4: 222. 1917. Type: Brazil. São Paulo, Cantareira, s.d., R. Davie 151 (holotype E!). syn. nov.

$=P$. arrojadii f. rigida Kük., Bot. Jahrb. Syst. 75: 470. 1952. Type: Brazil. Rio de Janeiro, 4 jun 1946, Cordeiro 55931 (holotype B!, isotype R!).

$=P$. arrojadii f. latifolia Kük., Bot. Jahrb. Syst. 75: 470. 1952. Type: Brazil. Rio de Janeiro, Santa Maria Magdalena, Serra da Matiqueira, s.d., A. Brade \& S. Lima 11579 (holotype B!, isotype R!).

Endemic to Brazil and widespread in the central-southern part of the Atlantic Forest from the states of Bahia to Santa Catarina, including Minas Gerais (Alves et al. 2014). It can be very rare and known from small populations. It is found in wellestablished populations in some protected forest fragments but also on edges of forest fragments. In some states, no specimens have been collected recently. It is considered VU based on its area of occurrence and small natural populations. It is possible that it is locally extinct in some states. This species can be recognized by the leafy culm combined with a loosely branched synflorescence with clustered spikelets.

Representative material examined: BRAZIL. BAHIA: Uruçuca, Parque Estadual Serra do Conduru, 28.IX.2000, W. Thomas et al. 12159 (CEPEC, NY). ESPIRITO SANTO: Linhares, Reserva Natural da CVRD, 20.III.2003, D. Folli 4483 (CVRD, UFP). MINAS GERAIS: Marciléia, Parque Estadual do Rio Doce, X.1993, L. Costa (BHCB, UFP). PARANÁ: Morretes, Serra Marumbi, 13.XI.970, G. Hatchbach 25376 (HB, K, MBM). SANTA CATARINA: Ilhota, Morro do Baú, D. Falkenberg 3566 (FLOR).

5. Pleurostachys gaudichaudii Brongn. in Duperr., Voy. Coq. Bot.: 174. 1829. Nemochloa gaudichaudii (Brongn.) Nees in Mart., Fl. bras. 2(1): 152. 1842. P. foliosa var. gaudichaudii H. Pfeiff., Feddes Repert 17: 332. 1921. Rhynchospora gaudichaudii (Brongn.) L.B. Sm., Phytologia 1: 81. 1934. Type: Brazil. Rio de Janeiro, s.d., Gaudichaudii 257 (holotype P!; isotypes G!, P!). $=$ P. gracilis Boeck., Allg. Bot. Z. Syst. 2: 111 . 1896. P. graminifolia var. gracilis (Boeck.) Kük. \& Gross., Bot. Jahrb. Syst. 75(4): 480. 1952. Rhynchospora hunnewellii (Boeck.) L.B. Sm., Rhodora 50: 132. 1948. Type: Brazil. Santa Catarina, Serra Geral, s.d., E. Ule 1612 (holotype $\mathrm{B}$ !, isotype $\mathrm{G}$ !, HBG!, K!, MO!).

$=P$. gaudichaudii f. minor Nees in Mart., Fl. bras. 2(1): 151. 1842. Type: Brasil. S. loc., s.d., Martius (holotype M!, isotype G!).

= P. polygonatum Palla, Akad. Wiss., Wien. Math.Naturwiss. Kl. 79: 186. 1908. Type: Brazil. Rio de Janeiro, Barra Mansa, Itapecerica, s.d., Wettestein \& Schiffner s.n. (holotype GZU, isotype BM!).

= Pleurostachys undulatifolia R. Gross, Feddes Rep. 42: 174. 1937. Type: Brazil. Rio de Janeiro, Santo Antônio de Imbé, s.d., A. Brade \& S. Lima 11573 (holotype B!, isotype HB!, R!).

Endemic to Brazil and widespread in the central-southern part of the Atlantic Coastal Forest from the states of Bahia to Rio Grande do Sul (Alves et al. 2014). It is found in well-established populations and in several protected forest fragments. It is considered LC based on the area of occurrence and the natural populations. This species can be misidentified as Hypolytrum bullatum C.B. Clarke because of the similarities of the general aspect of the plant and the undulate (bullate) leaves (Alves 2003) which is an easy character to distinguish it from other species of Pleurostachys.

Representative material examined: BRAZIL. BAHIA: Santa Luzia, Serra da Onça, 21.XI.1996, W. Thomas et 
al. 11365 (CEPEC, NY, RB). ESPIRITO SANTO: Santa Teresa, Estação Biológica da Caixa D'Água, 10.V.2001, M. Alves et al. 2351 (MBML, SP). PARANÁ: Nova Tirol, 28.IV.1970, G. Hatschbach 24202 (MBM, NY). SÃO PAULO: Peruíbe, Reserva Ecológica Juréia-Itatins, 7.VII.2000, M. Alves et al. 1783 (NY, SI, SP, UFP). RIO GRANDE DO SUL: Morrinhos, VIII.1992, M. Sobral \& J. Jarenkow 7303 (SP).

6. Pleurostachys macrantha Kunth, Enum. Pl. 2: 286. 1837. Nemochloa macrantha Nees in Mart., Fl. bras. 2(1): 151. 1842. Type: Brazil. Rio de Janeiro, s.d., Gaudichaud 255 (holotype P!; isotype $\mathrm{G}$ !).

It is endemic to Brazil and occurs occasionally in the central part of the Atlantic Forest from the states of Bahia to São Paulo (Alves et al. 2014). It is found in small populations and in protected forest fragments and is considered VU. This species can be easily recognized among the other species by having the largest spikelets and achenes up to $7 \mathrm{~mm}$ long.

Representative material examined: BRAZIL. BAHIA: Jussari, road to Palmira, 4.II. 1993, J. Kallunki et al. 434 (NY, SPF). ESPIRITO SANTO: Santa Teresa, Valsunanga Velha, 16.VII.2000, C. Fraga et al. 660 (MBML). RIO DE JANEIRO: Magé, Santo Aleixo, 25.VI.1983, R. Guedes et al. 284 (RB); Rio de Janeiro, Morro do Pai Ricardo, 22.V.1983, D. Pedrosa et al. 883 (GUA). SÃO PAULO: Ubatuba, Morro do Corcovado, 8.IX.1998, O. Ribas et al. 2771 (MBM).

7. Pleurostachys orbignyana Brongn. in Duperr., Voy. Coq. Bot.: 175. 1829. Nemochloa orbignyana (Brongn.) Nees, Linnea 9: 299. 1834. Rhynchospora orbignyana (Brongn.) L.B. Sm., Phytologia 1(2): 81. 1934. Type: Brazil. Rio de Janeiro, s.d., A. D'Orbigny s.n. (holotype P!).

= Nemochloa beyrichii Nees in Mart., Fl. bras. 2(1): 152. 1842. P. beyrichii (Nees) Steud., Syn. Cyp.: 139. 1855. Rhynhospora fluminensis L.B. Sm., Phytologia 1(2): 81. 1934. Type: Brazil. Rio de Janeiro, s.d., Sellow s.n. (holotype B not found and probably destroyed). syn. nov.

= Nemochloa extenuata Nees in Mart., Fl. bras. 2(1): 152. 1842. P. extenuata (Nees) Steud., Syn. Cyp.: 139. 1855. Type: Brazil. Rio de Janeiro, s.d., Martius 77 (holotype M!). syn. nov.

$=$ Nemochloa millegrana Nees in Mart., Fl. bras. 2(1): 152. 1842. P. millegrana (Nees) Steud., Syn. Cyp.: 139. 1855. Rhynchospora millegrana (Nees) L.B. Smith, Phytologia 1(2): 81. 1934. Type: Brazil. Rio de Janeiro, s.d., Martius 59 (holotype M!). = Rhynchospora millegrana Griseb., Fl. Brit.
West Ind.: 575. 1864. Type: Trinidad. s.loc., s.d., Grisebach s.n. (holotype GOET!). syn. nov.

$=P$. beyrechii f. pertensis Boeck., Kjobenh. Vidensk. Meddel. 1869: 150. 1869. Typus - Brazil. Rio de Janeiro, Corcovado, s.d., Gaudichaudii s.n. (holotype: P not found, isotype: G!). syn. nov. $=P$. grandifolia Boeck., Kjoejb. Vidensk. Meddel 1879/1880. P. millegrana var. grandifolia (Boeck.) H. Pfeiff., Feddes Repert. 17: 235. 1921. Type: Brazil. S.loc., s.d., Glaziou 6985 (holotype C, isotypes $\mathrm{K}$ !, $\mathrm{P}$ !).

= P. puberula Boeck., Flora 63: 453. 1889. Rhynchospora puberula (Boeck.) L.B. Sm., Phytologia 1: 82. 1934. Type: Brazil. Rio de Janeiro, s.d., Glaziou 11651 (holotype B!, isotypes G!, K!, P!). syn. nov.

$=P$. paniculata Boeck., Beitr. Cyper. 2: 20. 1890 . Type: Brazil. Rio de Janeiro, s.d., Mendonça 1310 (holotype B not found and probably destroyed).

$=$ P. montana Palla, Akad. Wiss. Wien, MathNaturwiss. K1. Denkschr. 79: 184. 1908. P. puberula var. montana (Palla) Kük \& R. Gross, Bot. Jahrb. Syst. 75(4): 478. 1952. Type: Brazil. Minas Gerais (Rio de Janeiro), Itatiaia, IX.1901, Wettestein \& Schiniffer 1261 (holotype GZU). syn. nov.

$=P$. beyreichii var. panicoides $\mathrm{H}$. Pfeiff., Feddes Repert. 17:234. 1921. Brazil. Paraná, Tamandaré, 24.IX.1914, G. Joansson (Dusén) 990a (holotype $\mathrm{B}$ !, isotype: $\mathrm{G}$ !).

$=P$. beyreichii var. angustocarpa $\mathrm{H}$. Pfeiff., Feddes Repert. 17:234. 1921. Brazil. Paraná, Serrinha, 1908, R. Dusén s.n. (holotype BREM).

$=P$. robusta Palla ex Buchtien in Luetz., Estud. Bot. Nord. Braz. 3: 89. 1923. Typus: Brazil. Rio de Janeiro, IX.1907, O. Buchtien 1228 (holotype G!). syn. nov.

$=P$. guianensis Uittien, Recueil Trav. Bot. Néerl. 22: 337. 1925. Type: Suriname. S.loc., 11 mar 1922, Emmaketen 5778 (U, B photo!).

$=$ P. millegrana var. minuscula Kük., Repert. Spec. Regni Veg. 26: 254. 1929. Type: Brazil. Pará, Mapiri, 2 nov 1926, O. Buchtien 332 (holotype $\mathrm{B}$ !, isotype $\mathrm{HBG}$ !).

$=$ P. buchtienii Kük., Repert. Spec. Regni Veg. 26: 254. 1929. P. puberula Boeck. var. buchtienii (Kük.) Kük., Bot. Jahrb. Syst. 75: 477. 1952. Type: Brazil. Pará, Mapiri, 2.XI.1926, O. Buchtien 337 (holotype B!, isotype HBG!). syn. nov.

It is the most widespread species of the genus and occurs in the Atlantic Forest (Brazil from the 
states of Pernambuco to Santa Catarina including Minas Gerais) and in the Amazon Forest in Bolivia, Colombia, French Guyana, Guyana, Ecuador, Peru, Suriname, Trinidad \& Tobago, Venezuela, and Brazil in the states of Acre and Rondônia (Govaerts et al. 2007: Alves et al. 2014). It is found in small and large populations and in protected forest fragments. It is considered LC based on the area of occurrence and the natural populations. This species can be easily recognized by the leafy habit and branched inflorescence associated with small spikelets up to $3.5 \mathrm{~mm}$ long. Two names have been largely used to identify samples of this species: $P$. beyrichii and $P$. pubera, both proposed here as new synonyms. After a large set of samples analyzed from different localities especially from Brazil, it is clear that the variation in leaf length, number of branches in the synflorescence and achene size is widespread in the taxon, making it impossible to use regular macromorphological characters to recognize different species as had previous been done by Govaerts et al. (2007) and Alves et al. (2009, 2014). Population studies under a molecular approach can provide a better understanding and maybe result in the recognition of more than one taxon.

Representative material examined: BRAZIL. ACRE: Rio Branco, Parque Zoobotânico, 4.II.1993, C. Figueiredo et al. 129 (HPZ). PERNAMBUCO: Caruaru, 29.VIII.1980, D. Andrade-Lima et al. 25 (IPA). RIO DE JANEIRO: Santa Maria Madalena, Mata de Urugão, 18.II.1981, S. Mayo et al. (K, RB). PARANÁ: Campina Grande do Sul, 17.VIII.1966, G. Hatchbach 14616 (MBM, P). SANTA CATARINA: Papanduva, Picadas, 13.V.1931, R. Reitz \& R. Klein 13531 (B, G, HBR, K).

8. Pleurostachys pilulifera (Bertol.) Longhi-Wagner, Baldini \& A.C. Araújo, Kew Bull. 65(3): 452-453. 2010. Rhynchospora pilulifera Bertol., Opusc. Sci. 3: 406. 1819. Type: Brazil. (Rio de Janeiro), s.d., Raddi s.n. (holotype BOLO!, isotypes G!, PI!).

$=$ P. graminifolia Brongn. in Duperr., Voy. Coq. Bot.:174. 1829. Rhynchospora graminifolia (Brongn.) L.B. Sm., Phytologia 1(2): 81. 1934. Type: Brazil. Rio de Janeiro, s.d., Guadichaud s.n. (holotype P!).

= P. schottmuelleri Boeck., Flora 65: 27. 1882. Type: Brazil. Rio de Janeiro, s.d., Schottmueller s.n. (holotype B not found and probably destroyed). =P. angustifolia Boeck., Beitr. Cyper. 2: 19. 1890 . Type: Brazil. Rio de Janeiro, Teresópolis, Serra dos Órgãos, s.d., H. Schenck s.n. (holotype B not found and probably destroyed).

$=P$. graminifolia var. glabra R. Gross \& Kük.,
Bot. Jahrb. Syst. 75(4): 480. 1952. Type: Brazil. São Paulo, Alto da Serra, 2.II.1908, A. Usteri 9341 (holotype SP). syn. nov.

Endemic to Brazil and known from montane Atlantic Forest in the states of Rio de Janeiro and São Paulo (Alves et al. 2014). It should be classified as VU because of the small number of known populations and most of the collections dating back more than 30 years ago. It can be recognized by the small size of the plants (up to $50 \mathrm{~cm}$ tall), the leafy culm and the spikelets very-clustered in the synflorescence which is short-pedicelate. Longhi-Wagner et al. (2010) recently proposed a new name and synonym under this taxon which is here followed.

Material examined: BRAZIL. RIO DE JANEIRO: Petrópolis, Pedra Comprida, 10.VIII.1968, D. Sucre 3473 (NY, RB), Rocio, 18.I.1968, D. Sucre \& \& P. Braga 2265 (HB, RB); Teresópolis, Serra dos Órgãos, 1877, J.F. Moura (R); 19.IX.1929, A. Brade 9263 (B). SÃO PAULO: Ilha Bela, Serra dos Castelhanos, 28.V.1970, D. Sucre et al. 6958 (RB, K).

9. Pleurostachys rabenii Boeck., Beitr. Cyper. 2: 20. 1890. P. stricta var. rabenii (Boeck.) H. Pfeiff., Repert. Spec. Nov. Regni Veg. 38: 98. 1935. Type: Brazil. Rio de Janeiro, s.d., C. Raben s.n. (holotype G not found).

$=P$. regnellii C.B. Clarke, Kew Bull. Add. Ser. 8: 41. 1908. Type: Brazil. Minas Gerais, s.d., Regnell 1319 (holotype $\mathrm{S}$ !, isotypes B photo!, P!). syn. nov.

It is another narrow-endemic species of the genus, restricted to southeastern Brazil (Alves et al. 2014) and known only from very restricted areas at high altitudes of the Serra da Mantiqueira (border of the sates of Minas Gerais, São Paulo and Rio de Janeiro) which is part of the Atlantic Forest domain. Few samples are available in local herbaria and its narrow-restricted distribution suggest it as VU. It is morphologically very close to $P$. stricta and $P$. brade $i$ which sometimes makes it difficult to distinguish specimens among all three taxa. However it can be recognized by the slender and longer culms and pedicels with a leafy bract. Further studies can show that all three names represent one species. However, for now it is not possible to confirm.

Material examined: BRAZIL. MINAS GERAIS: Passa Quatro, Estação Experimental, 3.V.1948, A. Brade \& S. Araújo 18933 (B, NY); Poços de Caldas, Morro São Domingos, 25.VIII.1964, O. Leoncini 130 (R). RIO DE JANEIRO. (Itatiaia) Serra de Itatiaia, X.1909, $R$. R. Dusén 2109 (R), idem, Monte Serrat, 15.VI.1930, A. Brade 10054 (R). 
10. Pleurostachys scaposa C.B. Clarke, Kew Bull. Add. Ser. 8:42. 1908.

Type: Brazil. Pará, Rio Purus, 5.IV.1904, O. Huber 4491 (lectotype MG photo!; isolectotype K!, IAN fragments! - designated here).

In Brazil, it is known only from a few samples from the type locality, which were collected a century ago. The samples available were collected in a juvenile stage which makes the reproductive characters unclear in some points. It grows in Peru and Brazil in the states of Acre and Pará (probably in the state of Amazonas too) in the Amazon Forest (Govaerts et al. 2007; Alves et al. 2014). The data available are insufficient for any indication of its conservation status. The species is morphologically related to P. orbignyana and has also been misidentified as Rhynchospora umbraticola Boeck.; all three species occur in the Amazon. However, P. sacaposa is distinguished by the less branched synflorescence and the pseudopetiolate leaves. More samples with mature achenes are mandatory for a better understanding of the morphological identity of this taxon.

Material examined: BRAZIL. ACRE: Rio Acre, IX.1911, E. Ule 9148 (G). PARA: Rio Purus, 5.IV.1904, O. Huber 4351 (MG, K). PERU. Loreto: Coronel Portillo, 2.IX.1968, J. Schunke 2742 (F, G).

11. Pleurostachys sparsiflora Kunth, Enum. Pl. 2: 286. 1837. Chaetosphora effusa Schrad., in sched. Nemochloa sparsiflora (Kunth) Nees in Mart., Fl. bras. 2(1): 151. 1842. Rhynchospora sparsiflora (Kunth) L.B. Sm., Phytologia 1: 82. 1934. Type: Brazil. S. loc., s.d., Schrad (B not found and possibly destroyed). Brazil. Amazonas: Manaus, Reserva Florestal Adolpho Ducke, 17 Nov 1999, M. Alves \& A. Amorim 1685 (neotype INPA!, isoneotypes NY!, SP!, UFP! - designated here).

= Pleurostachys opositiflora Kunth, in sched., syn. nov.

It is restricted to higher (50-200 m altitude) and dry areas of the Amazon Forest, locally called "Florestas de Terra Firme". It is found in Brazil, Colombia, Peru and Bolivia (Govaerts et al. 2007). In Brazil, this species is recorded from the states of Amazonas and Pará (Alves et al. 2014) but probably also grows in Acre and Mato Grosso. It is found in well-established populations and in several protected forest fragments and considered LC based on the wide area of occurrence and the numerous natural populations. It is morphologically related to $P$. macrantha which is restricted to the Atlantic
Forest and has larger spikelets and achenes. Among the species cited to the Brazilian Amazon basin (P. orbignyana and P. scaposa), P. sparsiflora is recognized by the slender and pendent pedicels of the synflorescence and the spikelets.

Representative material examined: BRAZIL. AMAZONAS: Itapiranga, rio Uatumã, 21.VIII.1979, C. Cid et al. 646 (INPA, NY); Manaus, Campus Embrapa, 8.VIII.1977, J. Albuquerque 27 (INPA), Reserva Florestal Ducke, 8.I.2002, M. Alves et al. 2341 (INPA, UFP). PARA: Itaituba, Parque Nacional do Tapajós, 17.XI.1978, M. Silva \& C. Rosário 3799 (K, NY, MG).

12. Pleurostachys stricta Kunth, Enum. Pl. 2: 286. 1837. Nomochloa stricta (Kunth) Nees in Hook., J. Bot. 2: 398. 1840. Nemochloa stricta (Kunth) Nees in Mart., Fl. bras. 2(1): 152. 1842. Type: Brazil. Brasilia meridionalis, s.d., Sellow s.n. (holotype K!).

= Rhynchospora panicoides Schrad ex Nees in Mart., Fl. bras. 2(1): 154. 1842. = P. muelleri Boeck., Beitr. Cyper. 2: 19. 1890. P. muelleri f. normalis Boeck., Allg. Bot. Z. Syst. 2: 111. 1896. Type: Brazil. Santa Catarina, Blumenau, s.d., E. Ule 1336 (holotype $\mathrm{B}$ not found and possibly destroyed, lectotypus HBG!, isolectotypus HBG!, $\mathrm{P} !$ - designated here).

=P. spicata Boeck., All. Bot. Zeitschr. 2: 112. 1896. Type: Brazil. Rio de Janeiro, s.d., A. Glaziou 18600 (holotype B not found and possibly destroyed, lectotypes G!, isolectotypes $\mathrm{K}$ !, P! - designated here).

= P. stricta var. angustocarpa $\mathrm{H}$. Pfeiff., Repert. Spec. Nov. Regni Veg. 17: 234. 1921. Type: Brazil. Paraná, Serrinha, 1908, R. Dusén s.n. (holotype BREM).

$=P$. calyptrocaryoides $\mathrm{R}$. Gross, Feddes Repert 42: 175. 1937. Type: Brazil. Rio de Janeiro, Angra dos Reis, Jussaral, A. Brade 14946 (holotype B!, isotype RB!).

$=P$. hoehneana $\mathrm{R}$. Gross, Feddes Repert 42: 175 . 1937. Type: Brazil. São Paulo, Alto da Serra, 15 aug 1895, G. Edwall 3154 (holotype B!).

= P. stricta var. dissoluta Kük. \& R. Gross., Bot. Jahrb. Syst. 75(4): 482. 1952. Type: Brazil. Rio de Janeiro, Alto da Boa Vista, oct 1931, A. Brade 8646 (holotype B!, isotypes G!, R!).

It is widespread in the central and southern part of the Atlantic Forest from southern Bahia to Rio Grande do Sul (Alves et al. 2014). It grows in well-established populations on the border of several protected lowland forest fragments and also in rocky outcrops and sandy soil. It is considered LC 
based on its wide area of occurrence and numerous natural populations. As stated previously, $P$. stricta is morphologically close to $P$. brade $i$ and $P$. rabenii which are narrow-endemics in the mountains on the border of the states of Minas Gerais, Rio de Janeiro and São Paulo. Specimens of P. stricta are often recognized by the medium-length rhizome with fibrous brownish to reddish sheath, coriaceous and somewhat rigid and erect leaves when dried and the single spikelets with short and erect pedicels. Pleurostachys stricta var. dissoluta has been cited as a synonym of $P$. stricta by Govaerts et al. (2007) and is accepted as such here. However, the type specimens (A. Brade 8646 at B, G and R) have branched inflorescences somewhat different from the general aspect often found in P. stricta which was also noticed by Kükenthal (1952). For a better understanding of this variation more collections from the area are mandatory.

Representative material examined: BRAZIL. BAHIA: Itanhém, Fazenda Pedra Grande, 18.III.2001, W. Thomas et al. 12328 (CEPEC, NY). ESPIRITO SANTO: Linhares, Reserva da Vale do Rio Doce, 6.X.1971, T. Santos et al. 2069 (CEPEC). RIO DE JANEIRO: Rio de Janeiro, Pedra do Itaúna, 30.XI.1969, D. Sucre \& D. Dunn 6033 (K, NY). PARANÁ: Porto Vitória, 16.XII.1966, G. Hatchbach 14932 (K, MBM, NY, P). RIO GRANDE DO SUL: Caxias do Sul, Ana Rech, 20.X.2001, A. Kegler 1150 (G, UCS)

13. Pleurostachys tenuiflora Brongn. in Duperr., Voy . Coq. Bot.: 175. 1829. Nemochloa tenuiflora (Brongn.) Nees in Mart., Fl. bras. 2(1):149. 1842. Rhynchospora tenuiflora (Brongn.) L.B. Sm., Phytologia 1(2): 82. 1934. Type: Brazil. Rio de Janeiro, 1833, Gaudichaudii 258 (holotype P!; isotype $\mathrm{G} 4 \mathrm{x}$ !, $\mathrm{P}$ !).

=Scirpus latifolius Berol., Opusc. Sci. 3:406. 1819. Isolepis latifolia (Berol.) A. Dietr., Sp. P1. 2: 132. 1832. Type: Brazil. S. loc., 1819, D. Raddi s.n. (holotype BOLO!, isotypes FI, G! PI!). Non Scleria latifolius Gilbert, 1972.

$=$ Nomochloa turbinata Nees in Meyen, Reise Erde 1: 108. 1834. P. turbinata (Nees) H. Pfeiff., Repert. Spec. Nov. Regni Veg. 19: 295. 1924. P. kunthiana C.B. Clarke, Kew Bull. Add. Ser. 8: 42. 1908. nom. sup. Type: Brazil. Rio de Janeiro, s.d., Meyen 282, 881 (syntypes CGE). syn. nov.

= P. floribunda Kunth, Enum. Pl. 2: 285. 1837. P. tenuiflora var. floribunda (Kunth) H. Pfeiff., Bot. Arch. 9: 228. 1925. Type: Brazil. Rio de Janeiro, s.d., Gaudichaudii 258 (holotype BREM, isotype: $\mathrm{P}$ !).
= P. elegans Kunth, Enum. P1. 2: 285. 1837. P. tenuiflora var. elegans (Kunth) H. Pfeiff., Bot. Arch. 9: 231. 1925. Type: Brazil. Rio de Janeiro, s.d., Gaudichaudii s.n. (lectotype P!, isolectotypes G!, P! - designated here).

= Nemochloa martiana Nees in Mart., F1. bras. 2(1): 150. 1842. P. martiana (Nees) Steud., Syn. Cyp.: 139. 1855. P. martina (Nees) Boeck., Linnaea 37: 646. 1871. Rhynchospora martiana (Nees) L.B. Sm., Phytologia 1(2): 81. 1934. Type: Brazil. Rio de Janeiro, Serra dos Órgãos, s.d., Martius 73 (holotype $\mathrm{M}$ !).

= P. elegans var. B Boeck., Linnaea 38: 225. 1874. P. douglasii C.B. Clarke, Kew Bull. Add. Ser. 8: 41. 1908. Type: Brazil. Rio de Janeiro, s.d., Douglas s.n. (holotype B not found and probably destroyed). syn. nov.

$=$ P. paludosus H. Pfeiff. in Luetz., Estud. Bot. Nord. Braz. 3: 89. 1923. syn. nov.

= P. latifolia H. Pfeiff., Feddes Rep. 19: 295. 1924. Type: Brazil. Rio de Janeiro, Corcovado, s.d., Luetzelburg 6018 (holotype BREM, isotype M!, NY!, R!).

$=$ P. luetzelburgiana H. Pfeiff., Feddes Rep. 19: 294. 1924. Type: Brazil. Rio de Janeiro, Serra dos Órgaos, s.d., Luetzelburg 6428 (holotype BREM, isotype M 2x!, R!).

$=$ P. tenuiflora var. longifolia Kük \& R. Gross, Bot. Jahrb. Syst. 75(4): 460. 1952. Type: Brazil. Rio de Janeiro, Angra dos Reis, 29.XI.1935, A. Brade 14948 (holotype B!, isotype R!).

It is widespread in the southern part of the Atlantic Forest from the states of Espírito Santo to Santa Catarina including Minas Gerais (Alves et al. 2014). Although it was not cited by Guaglianone et al. (2008), it is possible that it could be found in similar vegetation types in northern Argentina and eastern Paraguay. It grows in wellestablished populations and in several protected forest fragments and considered LC based on the wide area of occurrence and numerous natural populations. The spikelets are elliptical and isolated at the end of each axis of the highly-branched sinflorescence. This species can be confused with $P$. urvillei, but it is easily distinguished by the lanceolate, larger and less clustered culm leaves. We fully agree with the nomenclatural reasons to use the name Pleurostachys tenuifolia (Scirpus latifolius Bertol. was published earlier) as suggested by Longhi-Wagner et al. (2010).

Representative material examined: BRAZIL. ESPIRITO SANTO: Flexeiras, Atílio Vivacua, 
10.III.1972, D. Sucre 8608 (K, RB). MINAS GERAIS: Represa Palmyra, 30.IX.1937, A. Brade 15926 (B, RB). RIO DE JANEIRO: Rio de Janeiro, Parque Nacional da Tijuca, 20.II.1984, R. Ribeiro et al. 450 (GUA). PARANÁ: Quatro Barras, Rio do Corvo, 4.VIII.1994, J. Silva 1342 (G, MBM). SANTA CATARINA: Ilhota, Parque Botânico do Morro do Baú, 8.IX.2002, M. Alves et al. 2754 (HBR, UFP).

14. Pleurostachys urvillei Brongn. in Duperr., Voy. Coq. Bot.: 173. 1829. Nemochloa urvilleii (Brongn.) Nees in Mart., Fl. bras. 2(1): 150. 1842. Rhynchospora scalaris L.B. Sm., Phytologia 1(2): 82. 1934. Type: Brazil. Santa Catarina, s.d., D'Urville s.n. (holotype P!).

= P. ulei Boeck., Beitr. Cyp. 2: 19. 1890. Type: Brazil. Santa Catarina, Itajaí, s.d., E. Ule 553 (holotype B!, isotypes HBG!, K!, P!, RB!).

$=P$. paranensis Palla, Denkschr. Math. Nat. K1. Akad. Wien 79: 185. 1908. P. urvillei var. paranensis (Palla) Kük. \& Gross., Bot. Jahrb. Syst. 75(4): 463. 1952. Type: Brazil. Paraná, Antonina, s.d., Wacket s.n. (holotype GZU, isotypes $\mathrm{B}$ !, BM!).

$=P$. paranensis var. dusenii H. Pfeiff., Feddes Repert. 17: 231. 1921. P. dusenii (H. Pfeiff.) H. Pfeiff., Bot. Arch. 9: 228. 1925. P. paranensis Palla f. dusenii (H. Pfeiff.) Kük. \& R. Gross., Bot. Jahrb. Syst. 75(4): 464. 1952. Type: Brazil. Paraná, prope Volta Grande, s.d., R. Dusén 8950 (holotype BREM, isotypes B photo!, BM!, S!). $=P$. paranensis var. ypirangensis $\mathrm{H}$. Pfeiff., Feddes Rep. 17: 231. 1921. P. ypirangensis $(\mathrm{H}$. Pfeiff.) H. Pfeiff., Bot. Arch. 9: 229. 1925. P. urvillei f. ypirangensis (H. Pfeiff.) Kük. \& R. Gross, Bot. Jahrb. Syst. 75(4): 464. 1952. Type: Brazil. Paraná, prope Volta Grande, 30.X.1914, R. Dusén 7078 (lectotype G! - designated here).

It is widespread in the southern part of the Atlantic Forest from the states of Rio de Janeiro to Santa Catarina (Alves et al. 2014), and is sympatric with $P$. tenuiflora. It probably grows in the Atlantic forest areas in Argentina and Paraguay too but was not cited by Guaglianone et al. (2008). It is found in well-established populations and in several protected forest fragments and is considered LC based on the wide area of occurrence and numerous natural populations. This species is easily recognized by the elliptical leaves and their acute and somewhat curved apex.

Representative material examined: BRAZIL. RIO DE JANEIRO: Nova Friburgo, Macaé de Cima,
7.II.1975, C. Farney 575 (NY, RB). SÃO PAULO: Peruíbe, Reserva Ecológica Juréia-Itatins, 6.II.2000, M. Alves et al. 1747 (CEPEC, NY, SI, SP, UFP). PARANÁ: Paranaguá, Pico Torto, 11.XI.1969, G. Hatschbach 22869 (K, MBM); Morretes, Estrada da Graciosa, 16.XII.1964, G. Davidse et al. 1241 (MBM, MO). SANTA CATARINA: Ilhota, Parque Botânico do Morro do Baú, 31.X.1989, D. Falkenberg 4480 (FLOR).

\section{Acknowledgements}

Financial support for field work resulting in collections of this genus was provided by the John D. and Catherine T. MacArthur Foundation, the National Science Foundation, and the Beneficia Foundation. We thank the curators of the herbaria we consulted and also CAPES for the fellowships.

\section{References}

Alves, M. 2003. Hypolytrum Rich. (Cyperaceae) nos Neotrópicos. Tese de Doutorado. Universidade de São Paulo, São Paulo. 167p.

Alves, M.; Wanderley, M.G. \& Thomas, W. 2003. Padrões de ditribuicão das espécies neotropicais de Hypolytrum (Cyperaceae). Boletim de Botânica da Universidade de São Paulo 21: 265-276.

Alves, M.; Araujo, A.C.; Prata, A.P.; Vitta, F.; Hefler, S.; Trevisan, R.; Gil, A.; Martins, S. \& Thomas, W.W. 2009. Diversity of Cyperaceae in Brazil. Rodriguésia 60: 771-782.

Alves, M.; Hefler, S.M.; Trevisan, R.; Silva Filho, P.J.S.; Ribeiro, A.R.O. 2014. Cyperaceae. In: Lista de Espécies da Flora do Brasil. Jardim Botânico do Rio de Janeiro. Available at $<$ http://floradobrasil. jbrj.gov.br/>. Access on 4 september 2014.

Goetghebeur, P. 1998. Cyperaceae. In: Kubitzki, K.; Huber, H.; Rudall, P.; Stevens, P. \& Stützel, T. Vascular flowering plants. Vol. 4. Springer, Berlin. Pp. 141-189.

Govaerts, R.; Simpson, D.; Bruhl, J.; Egorova, T.; Goetghebeur, P. \& Wilson, K. 2007. World checklist of Cyperaceae. Kew Gardens, London. 765p.

Guaglianone, R.; Marchesi, E.; Marticonera, C.; Araújo, A.C.; Mereles, F.; Alves, M.; Doohge, S.; González-Eliazondo, E.; Hefler, S.; López, M.; López-Sepulveda, P.; Trevisan, R. \& Wheeler, G. 2008. Cyperaceae. In: Zuloaga, F.O., Morrone, O. \& Belgrano, M.J. Catálogo de las Plantas Vasculares del Cono Sur (Argentina, Sur de Brasil, Chile, Paraguay y Uruguay). Vol. 1. Missouri Botanical Garden, Saint Louis. Pp. 302-401.

IUCN 2012. The IUCN Red List of Threatened Species. Version 2012.2. Available at $<$ http://www. iucnredlist.org > . Access on 20 may 2014. 
Kükenthal, G. 1952. Vorarbeiten zu einer Monographie der Rhynchosporoideae. Pleurostachys. Botanische Jahrbücher für Systematik, Pflansengeschichte und Pflanzengeographie 75: 451-497.

Longhi-Wagner, H.; Baldini, R. \& Araújo, A.C. 2010. Cyperaceae Raddianae: a nomenclatural and taxonomic study of the Cyperaceae published in G. Raddi's Agrostografia brasiliensis. Kew Bulletin 65: 449-461.

Pfeiffer, H. 1925. Monographia Pleurostachydearum. I. Pars specialis descriptioque specierum. Botanisches Archhiv 9: 225-242.

Reivoize, S. 1984. The grasses of Bahia. Kew Gardens, London. 301p.
Smith, L. 1934. Taxonomic notes on American phanerogams I. Phytologia 1: 81-82.

Thomas, W.W. \& Alves, M. 2008. Towards a Revision of the Genus Pleurostachys (Cyperaceae): preliminary Results. In: Naczi, N. \& Ford, B. Sedges: uses, diversity, and systematics of the Cyperaceae. Monographs in Systematic Botany from the Missouri Botanical Garden 108: 269-278.

Thomas, W.W.,Araújo, A.C.\&Alves, M. 2009.APreliminary Molecular Phylogeny of the Rhynchosporeae (Cyperaceae). Botanical Review 75: 22-29.

Thomas, W.W.; Alves, M: \& Trevisan, R. 2013. Anew species of Pleurostachys (Cyperaceae) from Atlantic coastal Brazil. Phytotaxa 126: 131-136. 